Acta vet. scand. 1984, 25, $10-20$.

From the Department of Clinical Chemistry, College of Veterinary Medicine, Swedish University of Agricultural Sciences, and National Veterinary Institute, Uppsala, Sweden.

\title{
EFFECTS OF 2-MERCAPTOETHANOL ON THE SOLUBILITY OF COPPER AND ZINC CONTAINING PROTEINS IN LIVER SAMPLES FROM NORMAL AND CHRONIC COPPER POISONED SHEEP
}

By

Kamal S. M. Hussein, A. Frank, B.-E. V. Jones and L.-E. Edquist

HUSSEIN, K. S. M., A. FRANK, B.-E. V. JONES and L.-E. EDQVIST: Eljects of 2-mercaptoethanol on the solubility of copper and zinc containing proteins in liver samples from normal and chronic copper poisoned sheep. Acta vet. scand. 1984, 25, 10-20. - The solubility of $\mathrm{Cu}$ and $\mathrm{Zn}$ binding proteins was studied in liver samples from clinically healthy and chronic copper poisoned sheep (CCP). Homogenized liver was divided by ultracentrifugation into cytosol and pellet. The cytosol was gelfiltrated, $\mathrm{Cu}$ and $\mathrm{Zn}$ contents were determined in the eluates as well as in the pellet. Liver homogenate, cytosol and pellet were treated with 2-mercaptoethanol (ME). The resulting clear solutions were fractionated by gel filtration followed by determination of the contents of the two metals in the eluates.

In CCP sheep the solubility of $\mathrm{Cu}$ containing proteins from the liver homogenate and pellet increased after incubation with ME.

The results suggest that in CCP sheep a considerable amount of Cu containing proteins are present in an insoluble form, which to some extent is resolubilized by ME.

chronic copper poisoning; sheep; Cu and Zn metallothionine; mercaptoethanol; gel-filtration.

Chronic copper poisoning is a wellknown problem in sheep production throughout the world. The morbidity in affected herds may approach $5 \%$, but the mortality is high and can exceed $75 \%$ (Bostwich 1982). During a first phase the animal accumulates copper in the liver without showing clinical signs of toxicity and without a detectable increase of $\mathrm{Cu}$ in blood.

Later an acute phase, the hemolytic crisis, occurs characterized by release of high amounts of copper from the liver into 
the blood causing hemolysis and clinical manifestations of CCP. The hemolytic crisis is considered to be induced by some stress, e.g. parturition, starvation, heat or disease.

In CCP sheep, large amounts of $\mathrm{Cu}$ have been found attached to metallothionein (MT) (Norheim 1980). MT is a low molecular weight protein, first isolated from equine renal cortex (Margoshes et al. 1957) and later also from liver and kidney of a wide variety of animal species. It contains about $30 \%$ cysteine residue while aromatic amino acids are absent (Margoshes et al. 1957). The synthesis of MT in the liver can be induced by heavy metals, e.g. $\mathrm{Cd}, \mathrm{Zn}, \mathrm{Cu}$ and $\mathrm{Hg}$. A role for MT in detoxification of these metals has been suggested (Foulkes 1982). This protein also plays a fundamental role in $\mathrm{Zn}$ homeostatis (Bremner \& Davies 1974).

Isolation and purification of MT from rat liver and horse kidney result to some extent in oxidation and a subsequent alteration of metal distribution pattern as shown by Minkel et al. (1980). These authors also demonstrated that the addition of ME to the liver homogenate prevented oxidation or the altered metal distribution of an oxidized sample could be restored.

The present study was undertaken to investigate the effect of $\mathrm{ME}$ on the content and relative distribution of $\mathrm{Cu}$ and $\mathrm{Zn}$ in both cytosol and pellet fractions of livers from normal and CCP sheep.

\section{MATERIAL AND METHODS}

Samples of livers were obtained from 4 (nos. 1-4) apparently normal slaughtered sheep and from 3 sheep (nos. 5-7) which died in a hemolytic crisis due to CCP. All liver samples were kept at $-70^{\circ} \mathrm{C}$ until analysed. Copper and zinc contents in the livers were analysed by atomic absorption spectrophotometry (AAS) on a model 303 Perkin-Elmer (Perkin-Elmer, USA) after automated wet ashing using concentrated nitric acid and perchloric acid $(7: 3 \mathrm{v} / \mathrm{v})$ in accordance with a method described previously (Frank 1976).

Fifteen $\mathrm{g}$ of each liver was homogenized in $30 \mathrm{ml}$ of trisbuffer $(0.01 \mathrm{~mol} / \mathrm{l}$ tris-HCl $1 \%$ butanol-1 buffer, $\mathrm{pH} \mathrm{8.0)}$ using an Ultra Turrax ${ }^{\circledR}$ type 18/10 homogenizer (Jankel \& Kunkel, W. Germany) for $1 \mathrm{~min}$. A second homogenization was performed using a B. Braun type 853202 homogenizer (B. Braun AG. W. Germany) at 1400 r.p.m. for $1 \mathrm{~min}$. The preparations were made 
at room temperature $\left(\sim 20^{\circ} \mathrm{C}\right)$. The homogenate was divided into 3 portions of $10 \mathrm{~g}$ each. Separation of subcellular particles from the cytosol was carried out in a Beckman ultracentrifuge model L8-85 (Beckman Instruments Inc., USA) at $85000 \mathrm{~g}\left(\mathrm{r}_{\mathrm{av}}=61\right.$ ) for $70 \mathrm{~min}$. at $4^{\circ} \mathrm{C}$ using rotor type $70.1 \mathrm{Ti}$. Five $\mathrm{ml}$ of the recovered cytosol was fractionated by gel filtration as described by Bremner \& Marshall (1974) with slight modifications. A column $(720 \times 26 \mathrm{~mm})$ was packed with Sephadex G 75 fine (Pharmacia Fine Chemicals, Sweden) in tris-buffer. This buffer was also used to elute the columns at a flow rate of $10 \mathrm{ml} / \mathrm{h}$. Eluates of $5 \mathrm{ml}$ volume were collected using an LKB Ultrorac ${ }^{\circledR} 7000$ fraction collector (LKB-Produkter AB, Sweden). The ultraviolet absorption of the eluate was recorded continuously at $280 \mathrm{~nm}$ with an LKB UVI-Cord II Ultraviolet Absorptiometer type $8303 \mathrm{~A}$. Each of these $5 \mathrm{ml}$ eluates were directly aspirated into AAS for determination of $\mathrm{Cu}$ and $\mathrm{Zn}$. The contents of these two metals in each eluate were added to obtain the total soluble amount of the respective metals.

Copper and zinc contents of the pellet were determined by AAS after wet digestion.

The second portion of the homogenate was ultracentrifuged as above. Five $\mathrm{ml}$ of the cytosol was treated with 2-mercaptoethanol (Carl Roth, W. Germany) at a concentration of $0.1 \mathrm{~mol} / \mathrm{l}$ for $72 \mathrm{~h}$ at $\sim 5^{\circ} \mathrm{C}$. Thereafter, the cytosol was processed as described above for non-ME-treated cytosol. The pellet was resuspended in tris-buffer to the original volume and treated with $\mathrm{ME}$ as above. After the incubation the mixture was ultracentrifuged and $5 \mathrm{ml}$ of the supernatant was gel-filtrated and $\mathrm{Cu}$ and $\mathrm{Zn}$ were determined in the eluates as described for the cytosol.

The third portion of the homogenate was treated with ME. After separation of the sub-cellular particles, $\mathrm{Cu}$ and $\mathrm{Zn}$ were determined both in the cytosol (after gel-filtration) and in the pellet.

The column was calibrated with blue dextran (MW 200000), ovalbumin (MW 43000), chymotrypsinogen A (MW 25000), ribonuclease A (MW 13700) and insulin (MW 6200) for determination of the molecular weight of the eluated proteins.

A paired t-test was performed to compare the obtained results. 


\section{RESULTS}

The molecular weight of fraction III was found to be approximately 8000 daltons. This fraction had low absorbance at $280 \mathrm{~nm}$ and contained high amounts of $\mathrm{Cu}$ and $\mathrm{Zn}$.

Total $\mathrm{Cu}$ and $\mathrm{Zn}$ contents of livers from normal sheep are shown in Table 1 and for CCP sheep in Table 2. Contents of $\mathrm{Cu}$ and $\mathrm{Zn}$ in the eluates were combined as described by Bremner \& Marshall (1974) to make 4 pooled fractions. The fractions were separated from each other by cutting the combined eluates at fixed elution volumes. The tables also show the relative distribution of soluble $\mathrm{Cu}$ and $\mathrm{Zn}$ containing proteins expressed as a percentage distribution of soluble metal among the four fractions. The soluble $\mathrm{Cu}$ containing proteins of the cytosol from normal sheep were distributed in fractions. I, II and III independently of ME treatment. Similarly, regardless of $\mathrm{ME}$ treatment, $\mathrm{Zn}$ containing proteins were present in all 4 cytosol fractions (I-IV), in 2 of the liver samples (nos. 1 and 2), while the other 2 (nos. 3 and 4) had no $\mathrm{Zn}$ in fraction III.

Figures 1 (a-d) and 2 (a-d) show the distribution pattern of soluble $\mathrm{Cu}$ and $\mathrm{Zn}$ containing protein in cytosol (a), ME-treated cytosol (b), supernatant from ME-treated pellet (c) and cytosol from ME-treated homogenate (d) of liver samples from animals no. 1 and 7 , respectively. No appreciable difference in the pattern between ME-treated and non-ME-treated cytosol was found ( $a$ and $b$ in Figs. 1 and 2).

As shown in Table 2, soluble $\mathrm{Cu}$ containing proteins in the ME-treated cytosol samples from CCP sheep were eluted in all 4 fractions. In the non-ME-treated cytosol, only 1 of the animals (no. 7) had $\mathrm{Cu}$ containing proteins in all 4 fractions. In 2 of the animals (nos. 6 and 7), most of the $\mathrm{Cu}$ was found in fraction III. Zinc was distributed in fractions I, II and IV, with no or only small amounts in fraction III.

When the pellet or homogenate from liver specimens of both normal and CCP sheep were incubated with ME, the amount of extractable $\mathrm{Cu}$ containing proteins increased in the supernatant, especially in the CCP sheep $(\mathrm{P}<0.05)$. When pellets were treated with $\mathrm{ME}$, the yield of $\mathrm{Cu}$ in the supernatant increased from a mean of $16 \%$ soluble of the total amount to $30 \%$ in normal sheep. In CCP sheep, the soluble amount increase from $30 \%$ of the total to $60 \%$ after ME treatment. The increase in soluble $\mathrm{Cu}$ 


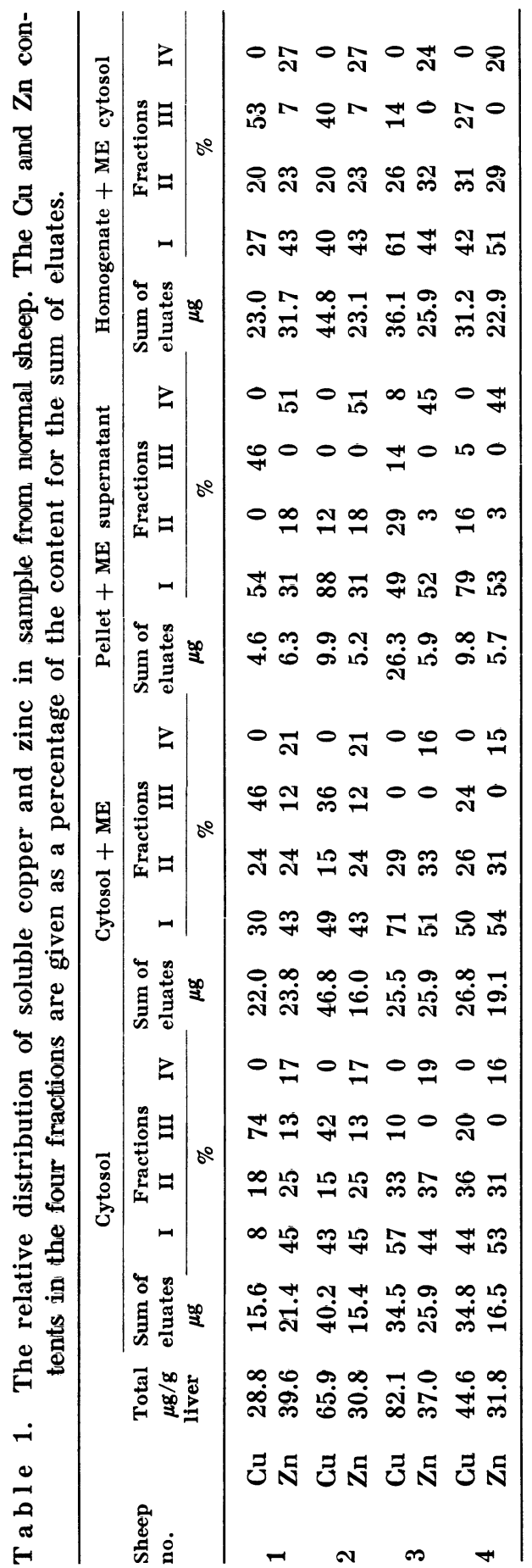

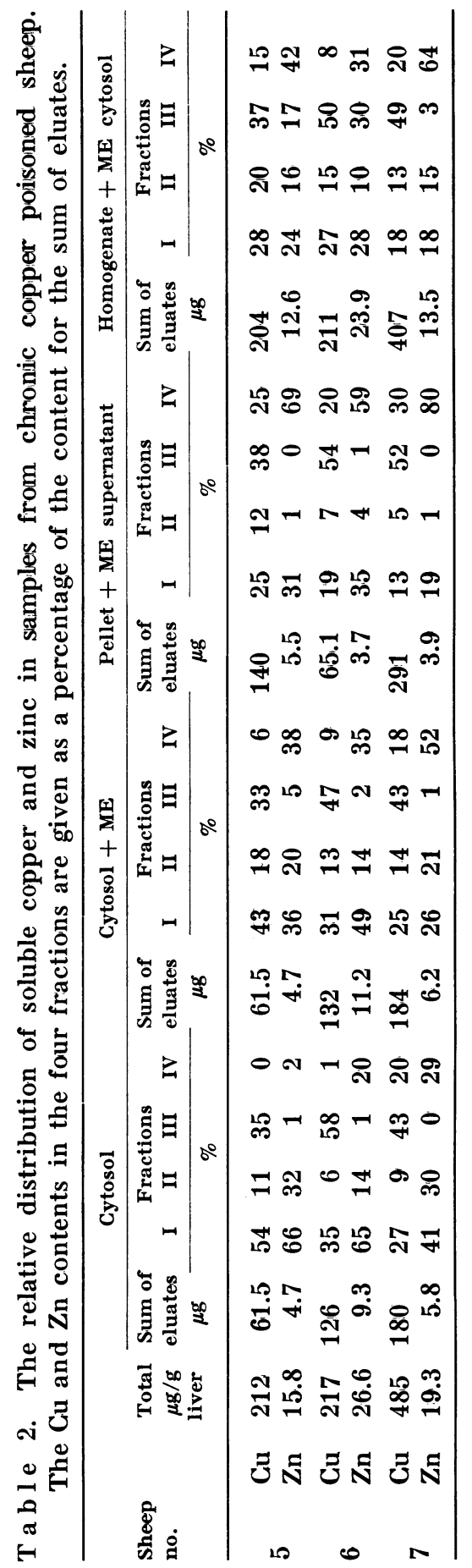



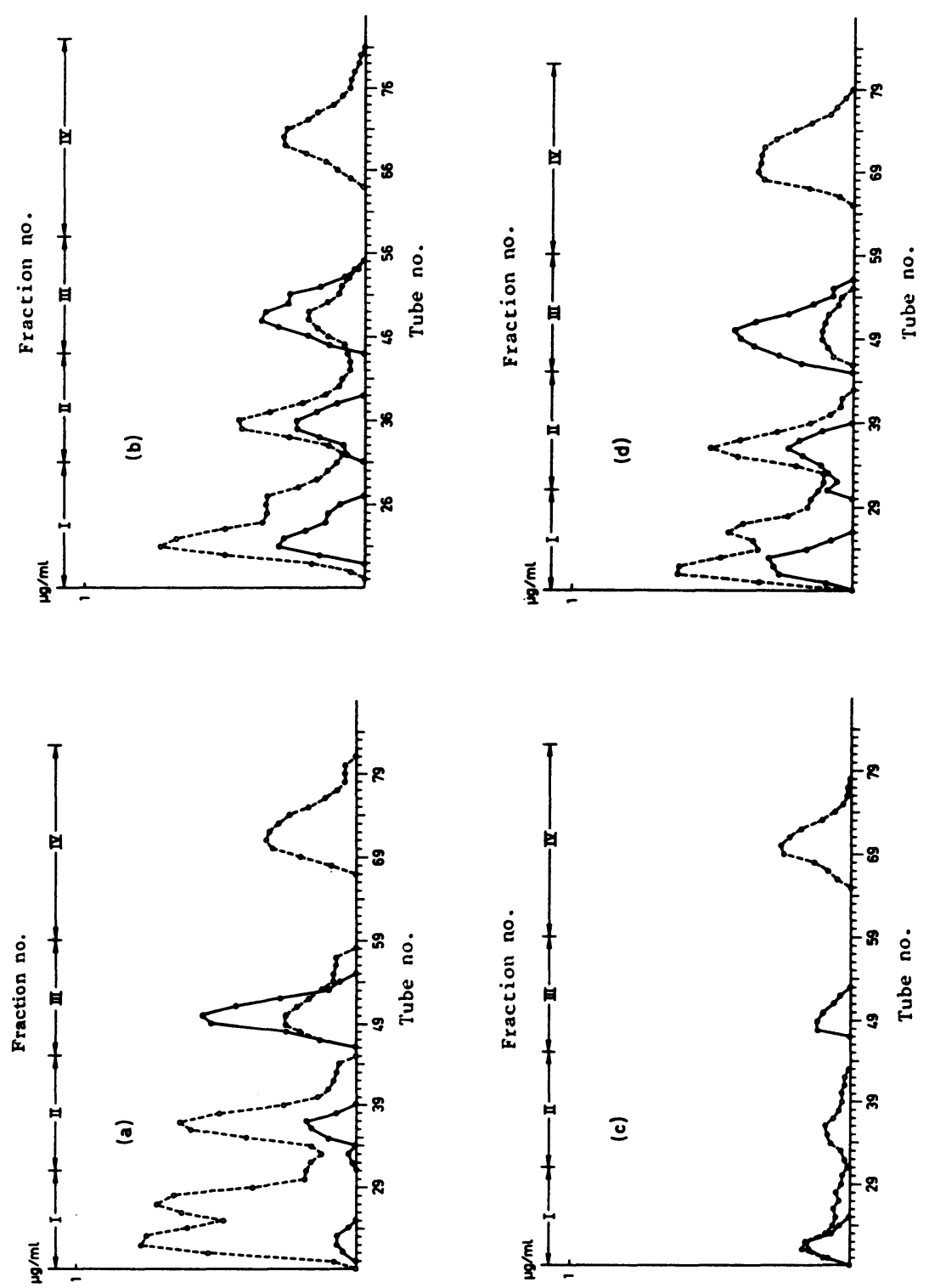

$\mathrm{F}$ i g u re 1. The distribution pattern of soluble $\mathrm{Cu}$ and $\mathrm{Zn}$ containing protein from liver sample of normal sheep.
$\mathrm{Cu}-\mathrm{O}-\mathrm{Zn}-\mathrm{O}-\mathrm{-O}-$
a) Cytosol
b) ME treated cytosol
c) Supernatant from ME treated pellet
d) Cytosol from ME treated homogenate 

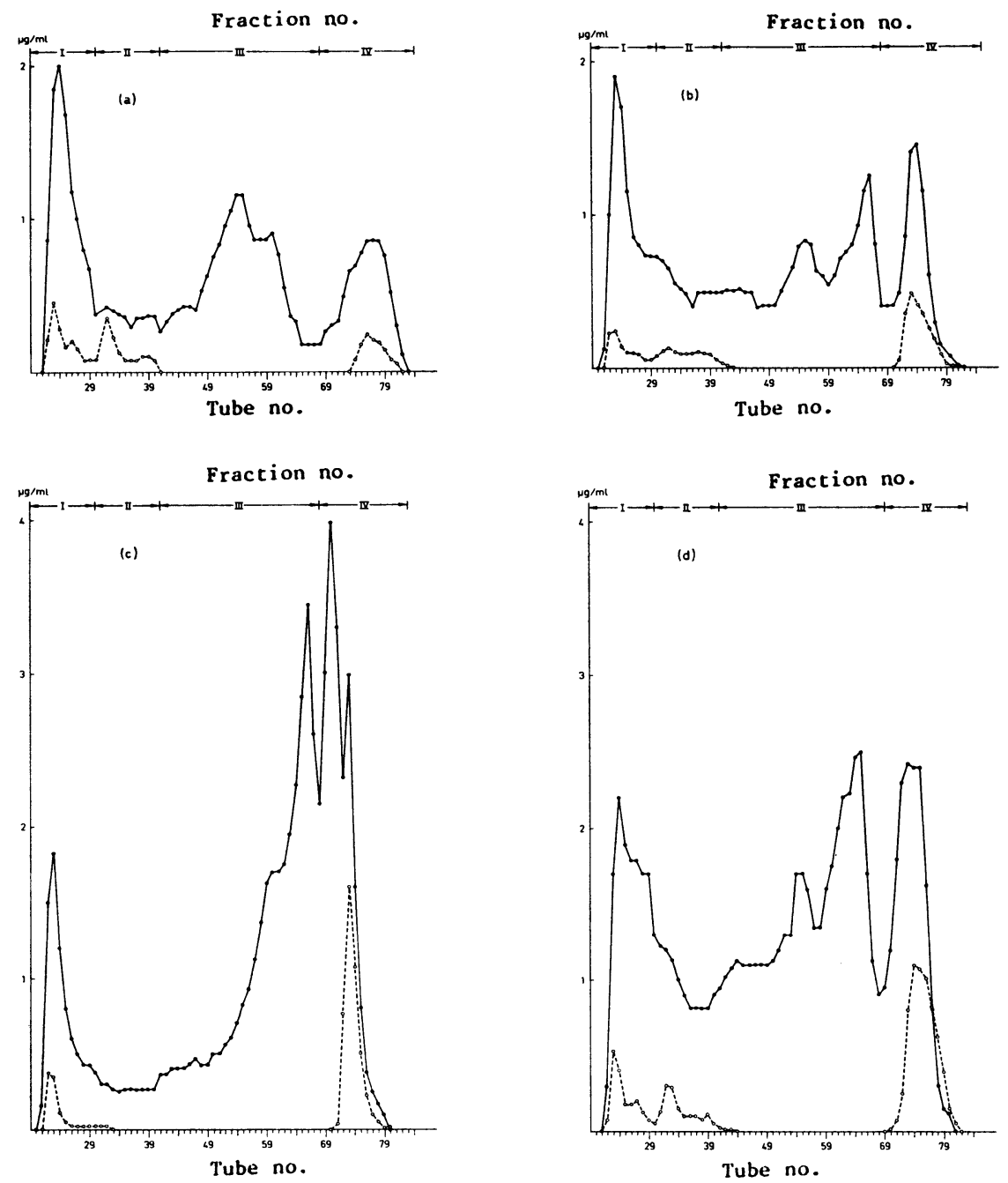

F i g u re 2. The distribution pattern of soluble $\mathrm{Cu}$ and $\mathrm{Zn}$ containing protein from liver sample of chronic copper poisoned sheep.

$\mathrm{Cu}-\mathrm{O}-\mathrm{O}-\mathrm{Zn}$-o--o-

a) Cytosol

b) ME treated cytosol

c) Supernatant from ME treated pellet

d) Cytosol from ME treated homogenate 
containing proteins as the result of ME treatment of the pellet or homogenate in normal and CCP sheep is visualized in Figs. 1c, d and $2 c$, $d$, respectively.

\section{DISCUSSION}

The low absorbance at $280 \mathrm{~nm}$ of fraction III, its molecular weight of about 8000 daltons and the high $\mathrm{Cu}$ and $\mathrm{Zn}$ content are characteristics of metallothioneins (Nordberg et al. 1978). The low absorbance at $280 \mathrm{~nm}$ is due to absence of aromatic aminoacids in these proteins. Aminoacid analysis was not performed in this case, but we consider the observed characteristics for metallothioneins sufficient to term fraction III metallothioneins.

The presence of soluble $\mathrm{Cu}$ containing proteins in fraction IV of cytosol from livers of CCP sheep but not in normal animals agrees with previous observations (Norheim 1980). According to Norheim (1980), the low $\mathrm{Zn}$ content in fraction III of CCP sheep could be due to a competition with copper for the same binding sites on the soluble proteins in this fraction. However, in the present study only 2 of the normal sheep (nos. 1 and 2 ) had appreciable amounts of $\mathrm{Zn}$ in fraction III. The 2 animals with no $\mathrm{Zn}$ in fraction III had low total $\mathrm{Cu}$ content in their livers and no $\mathrm{Cu}$ could be detected in fraction IV in these animals.

The present results show that the addition of $\mathrm{ME}$ to the pellet or the homogenate of liver samples from CCP sheep increases the amount of $\mathrm{Cu}$ containing soluble proteins which can be recovered in the supernatant or the cytosol. Such an effect was also observed by Porter (1968), who incubated samples from livers of newborn calves with ME. Since ME is a reducing agent, its effect could be attributed to an increase in the amount of monovalent $\mathrm{Cu}$ with a subsequent decrease in divalent $\mathrm{Cu}$. This is supported by the observation by Suzuki \& Maitani (1981) that bivalent Cu has to be reduced to monovalent in order to be incorporated into the soluble metallothionein. It has also been shown (Geller et al. 1982) that oxidation of cystein in Cu-thionein from rat liver reduces its affinity for $\mathrm{Cu}$. Another possibility is the ME acts by converting a structurally changed and insoluble MT to its soluble form, e.g. by depolarization of polymerized MT. According to Corbett $e$ al. (1978), the highest proportion of $\mathrm{Cu}$ is stored in the liver cytosol fraction of pre-hemolytic copper-loaded sheep, but Gooneratne et al. (1979) found the highest proportion of $\mathrm{Cu}$ stored in the nuclear fraction. The present results agree with the 
findings of Gooneratne et al. and, according to our results, the relative increase in $\mathrm{Cu}$ recovered from the soluble fraction following addition of $\mathrm{ME}$, represents $\mathrm{Cu}$ released from the subcellular fraction after reduction by $\mathrm{ME}$ and conversion of structurally changed MT to a soluble form.

However, ME treatment of cytosol from livers of normal or CCP sheep did not appreciably change the relative distribution of $\mathrm{Cu}$ or $\mathrm{Zn}$ containing proteins. Minkel et al. (1980) have shown that in oxidized liver cytosol from rats, $\mathrm{Cd}, \mathrm{Cu}$ and $\mathrm{Zn}$ moved from the metallothionein to higher and lower molecular weight proteins and that the addition of ME to the oxidized cytosol restored the original distribution pattern. In the present study, changes in the distribution pattern of $\mathrm{Cu}$ containing proteins were observed when the subcellular particles, either as resuspended pellet or as liver homogenate, were incubated with ME. The changes were more pronounced in CCP than in normal sheep. Treatment with ME seems to restore the solubility of $\mathrm{Cu}$ containing proteins changed by the altered redox potential in the hepatocytes during the hemolytic crisis.

An alteration of redox potential has been observed as a decrease in the amount of glutathion in blood just prior to and during the hemolytic crisis (Todd \& Thompson 1963, Todd 1969, Sфli et al. 1977).

Copper associated with the lysosome fraction of rat liver hepatocytes induces membrane changes and subsequent cell damage (Lindquist 1968). In CCP sheep, liver cell damage is evidenced by e.g. elevated blood plasma levels of ASAT and $\mathrm{Cu}$, which are known manifestations of the hemolytic crisis (Buckley et al. 1981).

\section{ACKNOWLEDGEMENTS}

This work was supported by the Swedish Council for Forestry and Agricultural Research. The pariicipation of Kamal S. M. Hussein was made possible by the Ministry of Agriculture and Animal Resources, Sudan.

\section{REFERENCES}

Buckley, W. T. \& R. M. Tait: Chronic copper toxicity in lambs. A survey of blood constituent responses. Canad. J. Anim. Sci. 1981, $61,613-624$.

Bremner, I. \& R. B. Marshall: Hepatic copper and zinc binding proteins in ruminants. 1. Distribution of $\mathrm{Cu}$ and $\mathrm{Zn}$ among soluble proteins of livers of varying $\mathrm{Cu}$ and $\mathrm{Zn}$ content. Brit. J. Nutr. 1974, 32, 283-291. 
Bostwick, J. L.: Copper toxicosis in sheep. J. Amer. vet. med. Ass. $1982,180,386-387$.

Corbett, W. S., W. W. Taylor, T. A. Long \& R. M. Leach Jr.: Intracellular distribution of hepatic copper in normal and copperloaded sheep. J. Anim. Sci. 1978, 47, 1174-1179.

Frank, A.: Automated wet ashing and multi metal determination in biological material by atomic absorption spectrometry. Z. Anal. Chem. 1976, 279, 101-102.

Foulkes, E. C. (ed.) : Biological roles of metallothionein. Developments in toxicology and environmental science. Vol. 9, Elsevier-North, Holland 1982.

Geller, B. L. \& D. R. Winge: Metal binding sites of rat liver Cu-thionein. Arch. Biochem. Biophys. 1982, 213, 109-117.

Gooneratne, S. R., J.McC. Howell \& J. Gawthorne: Intracellular distribution of copper in the liver of normal and copper loaded sheep. Res. Vet. Sci. 1979, 27, 30-37.

Lindquist, R. R.: Studies on the pathogenesis of hepatolenticular degeneration. The effect of copper on rat liver lysosomes. Amer. J. Path. 1968, 53, 903-927.

Minkel, D. T., K. Poulsen, S. Wielgus, C. F. Shaw \& D. H. Petering: On the sensitivity of metallothioneins to oxidation during isolation. Biochem. J. 1980, 191, 475-485.

Margoshes, M. \& B. L. Vallee: A cadmium protein from equine kidney cortex. J. Amer. chem. Soc. 1957, 79, 4813-4814.

Nordberg, M. \& Y. Kojima (eds.) : Metallothionein and other low molecular weight metal-binding proteins. Report from the First International Meeting on Metallothionein and Other Low Molecular Weight Metal Binding Proteins, 1978, p. 3.

Norheim, G.: Copper, zinc and molybdenum in sheep, swine and cattle in Norway. PhD thesis, National Veterinary Institute, Oslo, Norway 1980 .

Porter, H.: Neonatal hepatic mitochondrocuprein. Solubilization of the copper and protein from mitochondria of newborn liver by reduction with mercaptoethanol. Biochim. biophys. Acta 1968, 154, 236—238.

Suzuki, K. T. \& T. Maitani: Metal dependent properties of metallothionein. Replacement in vitro of zinc in zinc-thionein with copper. Biochem. J. 1981, 199, 289—295.

$S \phi l i, N$. E. \& A. Fr $\phi s l i e:$ Chronic copper poisoning in sheep. The relationship of methaemoglobinemia to Heinz body formation and haemolysis during the terminal crisis. Acta pharmacol. toxicol. 1977, 40, 169-177.

Todd, J. R.: Chronic copper toxicity of ruminants. Proc. Nutr. Soc. 1969, 28, 189-198.

Todd, J. R. \& R. H. Thompson: Studies on chronic copper poisoning. Biochemical studies on the blood of sheep during the haemolytic crisis. Brit. vet. J. 1963, 119, 161-173. 


\section{SAMMANFATTNING}

Effekten av 2-merkaptoetanol på lösligheten hos koppar- och zinkhaltiga proteiner $i$ leverprover från normala och kroniskt kopparförgiftade får.

Lösligheten hos $\mathrm{Cu}$-och Zn-bindande proteiner undersöktes i leverprover från kliniskt friska får och får som dött i kronisk kopparförgiftning (KKF). Homogeniserade leverprover delades med ultracentrifugering i cytosol och pellet. $\mathrm{Cu}$ och $\mathrm{Zn}$ bestämdes i cytosolen efter gelfiltrering och i pelletten. Leverhomogenat, cytosol och pellet behandlades var för sig med 2-merkaptoetanol (ME). Den klara supernatanten gelfiltrerades, och de två metallerna bestämdes i eluatet.

Vid KKF ökade lösligheten hos Cu-haltiga proteiner i homogenat och pellet efter behandling med ME.

Resultaten visar att hos får med KKF befinner sig en betydande del av de normalt lösliga Cu-haltiga proteinerna $i$ en olöslig form, men de blir åter lösliga vid behandling med ME.

(Received November 29, 1983).

Reprints may be requested from: B.-E. V. Jones, the Department of Clinical Chemistry, Box 7038, S-750 07 Uppsala, Sweden. 